September 17-24. It was the last to be held under the presidency of C. Lallemand, who resigned and will be succeeded by W. Bowie (United States). Owing to the present economic depression, the subscriptions for the coming three years were reduced by one quarter, and provision was made for further reductions in exceptional cases. This will affect the budgets of the several associations that are combined in the Union, and it is uncertain, for example, whether the additional funds required for the continuance of the publication, from Oxford, of the International Seismological Summary will be available from the Association of Seismology. Another Association with large needs at the present time is that of Terrestrial Magnetism and Electricity, which desires to further, as much as possible, the reduction and discussion of the data obtained during the International Polar Year, 1932-33. The next meeting of the Union is to be held at Edinburgh in 1936.

\section{National Central Library}

IT is hoped that His Majesty the King, accompanied by the Queen, will open the new building of the National Central Library in Malet Place, London, W.C., on November 7, at 3.15 p.m. The National Central Library, founded in 1916 as the Central Library for Students, was reconstituted in 1930 , and in addition to supplying books to adult education classes it is now used as a reserve and clearing-house for all public, county, and university libraries of Great Britain. The new building has been provided and equipped by the Carnegie United Kingdom Trust at a cost of about $£ 50,000$.

\section{England to Australia Flight}

ON Wednesday, October 4, Air-Commodore Sir Charles Kingsford-Smith started on a flight from England to Australia. He flew a Percival 'Gull' cabin monoplane, fitted with a Gipsy Major engine. As we go to press (October 11), it is announced that he has reached Wyndham, on the north coast of Western Australia. The record for the England to Australia flight was held by Mr. C. W. A. Scott, who in 1932 took 8 days 20 hours 44 minutes. Kingsford-Smith followed roughly the same course as Mr. Scott, except that he chose a shorter crossing of the Timor Sea, from Sourabaya to Wyndham (about 1,250 miles) instead of to Port Darwin (nearly 1,400 miles).

\section{Announcements}

THE Christmas lectures this year at the Royal Institution, which will be the one hundred and eighth course of six lectures "adapted to a Juvenile Auditory", will be delivered by Sir James Jeans, commencing on Thursday, December 28.

Mr. W. E. Freeman has been appointed tobacco breeding officer, Mauritius (Colonial Agricultural Service).

Prof. R. A. Peters, Whitley professor of biochemistry in the University of Oxford, will deliver the twenty-third Bedson lecture of the Bedson Club at Armstrong College, Newcastle-upon-Tyne, on November 3, at 6.30 p.m. The title of Prof. Peters's lecture, which is open to the public, will be "Some Recent Aspects of the Vitamin B Complex".

Prof. A. F. C. Pollard, professor of technical opties in the Imperial College of Science and Technology, will deliver the Thomas Hawksley lecture before the Institution of Mechanical Engineers on November 3 at 6 p.m. The title of Prof. Pollard's lecture will be "Kinematic Design in Engineering".

WE have received a copy of the first number of the Independent, a weekly journal published by Sir Ernest Benn, price $6 d$. The journal is of general interest, dealing with economics and politics, art, everyday topics, books, drama, music, etc., but no attention is given in this first issue to scientific subjects other than economics.

Applications are invited for the following appointments, on or before the dates mentioned:-A technical assistant for clinical laboratory workGeneral Superintendent and Secretary, Manchester Royal Infirmary (Oct. 19). A mechanical and electrical engineer for the Royal Aircraft Establishment -A. 567, Chief Superintendent, R.A.E., South Farnborough, Hants (Oct. 20). A pathologist-Secretary, Queen Mary's Hospital for the East End, E.15 (Oct. 20, marked "Pathologist" in left hand top corner). A head of the Pharmacy Department at the Central Technical College, Birmingham-Particulars (stamped addressed foolscap envelope) from Principal, Central Technical College, Birmingham 1 (Oct. 21). A chief veterinary officer for the Essex County Council-Clerk, Essex County Council, Shire Hall, Chelmsford (Oct. 23). A lecturer in horticulture at the University of Leeds-Registrar (Oct. 23). An instructor in poultry husbandry in the Department of Agriculture, University of LeedsRegistrar (Oct. 25). Probationary inspectors (male) in the Engineering Department of the Post Office-Secretary, Civil Service Commission, London, W.1 (Oct. 26). An instructress in rural domestic economy in the Department of Agriculture, University of Leeds-Registrar (Nov. 6). An American international fellowship, offered by the American Association of University Women for 1934-35- "Research Applications", British Federation of University Women, London, S.W.3 (Nov. 18). Four Henry fellowships, available for British graduates and tenable for one year at Yale or HarvardSecretary, Henry Fund, c/o University Chest Office, Oxford (Jan. 1, 1934). An International residential scholarship at Crosby Hall, offered by the British Federation of University Women for 1934-35, and an International (American Fellowship Crusade) fellowship offered by the American Association of University Women for 1934-35-"Research Applications", British Federation of University Women, London, S.W.3 (Jan. 13, 1934). Grocers Company research scholarship for original investigations in sanitary science-Clerk to the Grocers Company, Grocers Hall, London, E.C.2 (April 29, 1934). 